Athens Journal of Humanities \& Arts - Volume 7, Issue 4, October 2020 - Pages 339-352

\title{
The Power of Greetings in African Christianity
}

\author{
By Humphrey Mwangi Waweru*
}

This is an original study of greetings among Christians in an African setting. Greetings have played a major role in the spread of Christianity in Africa and not much study has been done on this simple gesture of interaction. Greeting is not unique to the Africans it is a common phenomena. A common way of greeting within the Greek culture is 'Hello',

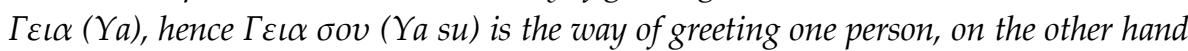
$\Gamma \varepsilon \iota \alpha \sigma \alpha \varsigma$ (Ya sas) is commonly used, when greeting more than one person. In Africa one uses greetings as a way of self introduction to a new person or even to an acquaintance. In both the Bible and modern Africa greetings have played a major role in the daily life of the people. It is a fundamental element among African Christians to greet one another in the name of God. 'Praise God' or 'Bwana asifiwe' (Kiswahili). Such are the most common words in greetings among African Christians. If one does not greet fellow Christians through these words something is terribly wrong and one is taken to be an enemy of God, people and the cross of Christ. African Christianity has used greetings as a way of expressing one's faith. In almost every Church you visit you will discover a common style of greeting. In some Pentecostal churches one will say 'God is good' (Ngai ni mwega) and the congregation will reply 'all the time' (hingo ciothe). Then one who is greeting will repeat 'And all the time' (hingo ciothe), congregation will reply 'God is good' (Ngai ni mwega). In the Catholic Church, one will say 'let us praise the Lord' (tumukumie yesu kristo) and the one being greeted will reply 'let us paise him all the time (tumukumie hindi ciothe) and so on. The Bible legitimates greetings as a way of mission either to already founded churches or churches to be. Recent studies have shown that greetings do not necessarily lead to mission, however, but to an ever greater encounter between two human beings. In particular, the relationship that develops between people who embrace greetings result into a fellowship of everyday life. This essay argues that the future of church mission will necessitate a reorientation from crusades in market places to living as mission oriented people at face level of individual relationships of house churches. The dialogue taking place on the plain of greetings and socialization is explored both ib Bible and African culture, along with a critical survey of various greetings and missioned stances towards it. At the end practical theological reflections are offered towards developing a style of life for mission centered on greetings.

\section{Introduction}

Greetings in the Bible as well in African Christianity are not a dry act performed for the sake of it. It is something both theological and contextual, with consequences that range from blessings, praises to punishment and curses ${ }^{1}$. Even

*Lecturer, Kenyatta University, Kenya.

1. H. Waweru, African Theology in a Postcolonial Perspective (Limuru, Kenya: Franciscan Kolbe Press, 2020): 153. 
in the Greek culture they often greet one another with a friendly and casual "yasou" (yasoo/yassou), the greeting is multi-purpose meaning 'how is your health' in Greek and meant to imply a well-wishing of good health to the person being greeted. Sometimes, in informal settings like a casual bar, the Greeks might also say "yasou" in the same way Kenyans say 'mambo' or Americans say 'cheers'. A good African Christian greets people well and is honored and praised in the society while one who does not is taken as a bad person, arrogant and proud or a scandal.

The aim of this paper is to demonstrate that greetings have turned out to be a religious ritual in African Christianity and a process rather than a single act or an event. In this case of greetings a religious ritual is understood as a celebration of life that affects those involved by touching their inner spiritual personalities by connecting them with the spiritual world through a procedure involving a series of activities, bodily gestures, and symbols ${ }^{2}$ which have already been formalized by the society. This is what greeting means in African Christianity. The research question is how we can enhance greetings as a tool for evangelism in the Church ${ }^{3}$.

\section{Purpose of Greetings}

When two people meet and say 'Praise God' to each other, it means joy not only because you are alive but also because you are still praising Jesus the savior of the world, hence a reason to rejoice and celebrate. It would also mean that you are both in full gratitude to God who brings everything into order and his light has continued to shine upon you. So when one says 'Bwana a sifiwe' and the other replies 'asifiwe Yesu' these are pregnant statements with no questions but both are answers to a number of questions, Are you still there, are you still existing, are you still alive, and the answer is, we are still alive, God is still in charge, and we are happy for his continued protection. So greeting a person in African Christianity is performing a whole ritual in a minute. Greetings are not only part of Christian theology but also a specific set of moral attitudes and behaviors that went along with mission in Africa ${ }^{4}$.

2. See Anthony P. Cohen (1985) who concludes that, symbols give the limits of cultured thought whereby people of the same culture rely on such symbols to frame their thoughts and expressions in intelligible terms. Nowhere else can this be better expressed than in greetings? For Cliford Geertz (1973) and Victor Tuner (1967) symbols are both the practices of social actors and the context that gives such practices meaning.

3. See Mercy Oduyoye "Claiming our Heritage: Africa in World Christianity (AsanteOpoku-Reindorf Lecture 2008)," in Journal of African Christian Thought, 12, no. 2 (2009): 7, wherer she argues that to assess or describe Christianity in Africa today, should be a question of research rather than a matter of pronouncements.

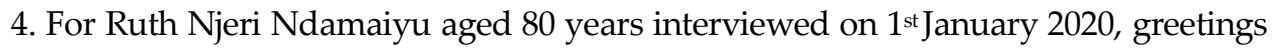
are part of 'popular Christianity' in Africa that embodies beliefs and practices that are the hallmark of the historic missionary enterprise. 
In Africa ritual is very important in that it is a 'key' or a 'bunch of keys' to unlock an understanding of the deepest values of a culture of the people ${ }^{5}$. Within African Christianity greeting points to nearly all basic needs of African Christianity such as hospitality, respect of human life, spirituality, societal aspects of life as well as connectedness of each other in the society. Greeting is a drama performed freely by all good-hearted people in a very short moment on the stage of humanity, actors being two or more people celebrating the joy of being alive, being in God who has made it possible for them to meet. During this short drama people ore overjoyed with gratitude because their creator and the giver of wisdom has continued to bless them. So in a short testimony people will quickly explain what has been of them for the last few days they have not met. Some will explain about rains or harvest or even sun for that matter in their areas'.

It is interesting to realize that although greeting in African Christianity has been given much value by the community nothing so far has been documented by African theologians and philosophers concerning this interesting area of life people share with the world 7 . So here we will explain greetings by looking at different ways of greeting, reasons for greeting and the behavior of those involved with greetings, But before that we need to reflect on the biblical foundations for greetings.

\section{Greetings in the Bible}

The Bible is a heritage for the African church which is at its disposal and it cannot afford to ignore. However the biblical theology will have to reflect the African context and understanding for it to offer an original contribution to the theology of the Church as a whole. This is best expressed in greetings as Paul and Peter demonstrates ${ }^{8}$.

5. See A. Shorter, (ed.) Church and Marriage in East Africa (Eldoret: A.M.EC.E.A, 1975), 61.

6. See David A. Brown, A Guide to Religions (London: SPCK, 1975), 3, where he argues that human beings are always looking for ways by which to improve their relationship with the world around them.

7. For Mercy Oduyoye (2009: 7), the attitude of contemporary spiritualism towards an intellectual grounding of the faith is not encouraging.

8. See John S. Mbiti, New Testament Eschatology in an African Background (London: Oxford Univ. Press, 1971), 189, 190; John S. Mbiti, "Some African Concepts of Christology," in G. F. Vicedom, ed., Christ and the Younger Churches, Theological Collections no. 15 (London: SPCK., 1972), 51; and John S. Mbiti, "The Future of Christianity in Africa (2000)," Communio Viatorum 13, no. 1-2 (1970): 32-33. 


\section{Case of Paul and Greetings}

1. Greet all the saints in Christ Jesus. The brothers who are with me send greetings. All the saints send you greetings especially those who belong to Caesar's household (Phil 4:21-22). Paul sends greetings as a sign of his social connection with the Churches he had either visited or started earlier.

2. Tychicus will tell you all the news about me. He is a dear brother, a faithful minister and fellow servant in the Lord. I am sending him to you for the express purpose that you may know about our circumstances and that he may encourage your hearts (Col 4:7-8). In this case Tychicus will not only carry greetings, but the whole information on how the mission works has progressed. He was given the task of encouraging the brethren with the greetings now not necessary in any letter but in his presence to them.

3. Greet all brothers with a holy kiss (1Athess 5:26). According to the fourth century Cyril of Jerusalem greetings are purposed to reunite Christians in a special way. "The Kiss therefore is the sign that our souls are mingled together and banish all remembrance of wrongs" (On the Mysteries V, Lecture 23, NF).

4. Greet Priscilla and Aquila and the house hold of Onesiphorus. Erastus stayed in Corinth, and I left Trophimus sick in Melitus. Do your best to get here before winter Eubulus greets you, and so do pudens, linus, claudia and all the brothers (2Tim 4: 19-21). So for Paul greetings is the singlehandedly the simplest way of inform brethren that you have been thinking about them. It is through greetings do the receipts appreciate the relationship already maintained between distanced people.

5. Epaphras, my fellow prisoner in Christ Jesus, sends you greetings. And so do Mark, Aristarchus, Demas and Luke, my fellow workers (Philemon 2324). Even in prison greetings will do the reuniting magic of togetherness with free brethren. So receiving greetings from prisoners makes those who are free part of the fellowship already in prison.

\section{Case of Peter and Greetings}

1. With the help of Silas, whom I regard as a faithful brother, I have written to you briefly encouraging you and testifying that this is the true grace of God. Stand fast in it. She who is in Babylon, chosen together with you, sends you greetings and so does my son Mark. Greet one another with a kiss of love (1Peter 5:12-13). Peter a great apostle emphasizes the significance of greetings to the brethren as a way of becoming one through the holy kiss. 


\section{African Different Styles of Greetings}

When the Bible arrived in Africa, it found a fertile ground to germinate on'. One such ground was in greetings which was cultural among the African people ${ }^{10}$. African Christians like many other peoples of the world use different styles to express their greetings such as word of mouth, embrace, handshake, waving, winking, patting on the shoulder or on the head, smiling, kissing as well as singing. Greetings expressed the African worldview ${ }^{11}$. No wonder majority of our people are feeling hard hit by Corona Virus, demand of social distancing. Africans are not able to comprehend how, to keep a social distance, perhaps because of what Mbiti says 'I am because you are, and because you are therefore I $\mathrm{am}^{\prime 12}$. He was a distinguished pioneer in the systematic analysis of traditional African religious concepts.

Throughout the continent African Christian greetings are expressed through the word of Praise to the almighty. Almost every Christian group has a formal verbal formula expressing greetings ${ }^{13}$. Either one will great by saying 'praise the Lord', and the rest will reply 'Amen' or by a chorus 'God is good' and people reply 'all the time' and 'All the time' they reply 'God is good'. In most cases the word of mouth is not enough. Greetings are generally accompanied with a good hand shake; a good hug particularly if people have not seen each other for a long time $^{14}$.

If one entered a big gathering and while walking in, notices a close friend particularly in Kikuyu society one can easily wink (kuna riitho) as an expression of greeting and recognition of the presence of the other in the same meeting ${ }^{15}$. In

9. See Waweru The Bible and the African Culture: Mapping Transactional Inroads (EldoretKenya: Zapf Chancery, 2011) ,5

10. Every society has its own culture, which simply means patterns of behavior, which are customary in any given society. Such distinguish that culture and the society to which it belongs. Cultural patterns are passed are passed on from one generation to another through time (Waweru 2011:5). Interestingly no one knows how greetings emerged within African traditions.

11. See Waweru (2005: 165-166) who says that, a worldview is a picture of the way things appear in sheer actuality, people's concept of nature, of self and society, where comprehensive ideas of order of life are expressed.

12. See John S. Mbiti, African Religions and Philosophy (African Writers Series. Heinemann, 1969), 108.

13. See Thomas C. Oden, How Africa Shaped the Christian Mind, Rediscovering the African seedbed of Western Christianity (Downers Grove, IL: IVP,2007), 146.

14. Says Peter Njenga, a retired Anglican bishop of Kenya Interviewed on 1oth January 2020 on the importance of greetings in spreading the Gospel.

15. H. Waweru, African Theology, 155. 
other Christian groups it may not be acceptable to wink to somebody ${ }^{16}$.

In almost all African Christian groups waving is acceptable as an expression of greeting when one is greeting another person at a distance and physical contact is hindered by distance. Greeting in such a circumstance is accompanied by a word of mouth or a smile depending on the situation. If it is in a garden where people are working a bit far from the road a word of mouth follows waving, but if the greeted was in a congregation where talking would be a bother then a smile comes in handy. A good smile is a real treasure to Christians; it enhances the human vital force of both the giver and the recipient.

Another common type of greeting is patting or laying of the hand on other peoples head or shoulder as an expression of happiness while greeting someone. Patting is mostly for people of the same age in Christianity. A young man may not feel comfortable to pat an old lady while a young woman may also not be comfortable patting or laying hands on the shoulders of elderly people. So this kind of greeting is specifically for birds of the same feathers. But in African tradition Maasai people do greet their young ones by laying hands on their hands, but not on shoulders ${ }^{17}$.

In African Christian circles kissing is specifically left to husbands and wives or to women alone. During marriages a number of pastors will allow the groom to kiss the bride as a way of greeting. In other words what the pastor allows in public must then continue to be practiced at home and during their years of marriage. Rarely would people use kissing as a way of greeting to other friends unless a daughter to a mother or a woman age mate ${ }^{18}$. This is not publically practiced although Paul advocates it.

\section{Reasons for Greeting in Africa}

There are a number of reasons why African Christians greet each other. As explained earlier greetings are not meaningless or empty rhetoric phrases in themselves. They are meant to convey special relationship to the one being greeted. African Christian greetings borrow heavily from the African culture and they contain the various basic contents.

16. Explains, Rev. Samuel Capt. Mwangi, winking may mean different things to different people, during a discussion of Christian greetings held early this year on $9^{\text {th }}$ February 2020.

17. Waweru, African Theology, 156.

18. Waweru, African Theology, 155. 


\section{Message of Peace and Blessings in Greetings}

As Jesus departed this world, one thing he promised his people was peace. 'Peace I leave with you; my peace I give you. I do not give to you as the world gives. Do not let your hearts be troubled and do not be afraid' (John 14:27). Christianity throughout the world is known as a religion of peace. African people are naturally lovers of peace even though the continent may portray different images. At the meeting point between Christianity and African culture peace is realized and enhanced. As we juxtapose these two seemingly unrelated-even antagonistic texts the meaning is found in greetings. In Africa meaning is not isolated 'inside' the text, for no text is an island'. Meaning is in the space 'between' texts. For Boer, a New Testament scholar biblical study is in itself a subset of religion, which belongs to the superstructure of the totality of society, sharing that space with art, culture, philosophy, politics and ideology ${ }^{19}$. In African Christianity such is best expressed in greetings.

For one to be peaceful within the community, one has to greet people whenever they meet. At the moment of waking up in the morning people have to greet even before they call for prayer. Greeting is given more priority to prayer. When people wake up in a new day it does not matter whether they slept in the same bed or not but they have to start their day by greeting each other. It is usually taken that on the sleep people were very far and waking up is a special come back that requires welcome from each other. In African Christianity greetings makes Jesus Christ as "the centre of our life". This is comparable to what John Stott in his book, The Incomparable Christ, describes Jesus Christ as 'the centre of history', the 'focus of Scripture', and the 'heart of Christian mission' ${ }^{20}$.

In African Christianity the very height of Christ's full stature is reached only by the coming together of the different cultural entitles into the body of Christ. They belong together as one of them is incomplete without the other; such is best expressed in greetings as a form of fellowship ${ }^{21}$.

What the above description points is the fact that the coming together of different people in greetings creates something new. Waking up is a wonderful thing and even a good reason to rejoice, so one greeting will say 'praise the Lord that we have woken up' so people will quickly respond to affirm the joy of waking up and having survived the darkness of the night. So this new day becomes an occasion to celebrate and thank God for it. Greeting in African Christianity involves asking questions about how the other people slept. In case these people greeting each other did not spend the night in the same home, then

19. See R. Boer, "Remembering Babylon: Postcolonial and Australian Biblica studies," in Sugirtharajah (ed.) The Postcolonial Bible (Sheffield: Sheffield Academic Press, 1998), 43.

20. John Stott, The Incomparable Christ (Downers Grove, IL: IVP, 2000), 15-16.

21. Cf. A. Walls, The Cross-Cultural Process in Christian History (Maryknoll: Orbis, 2002: 77). 
the greeting will go beyond them to all other members of the family left at home. The greetings may even last for over ten minutes. The greetings will express love and concern about the wellbeing of the other members of the family. Bible information held by Africans comes from socialization in the churches themselves as they listen to prayers and sermons; such is expressed best in greetings as a way of engaging each other. While luke warns such may even engage in gossip as part of greetings. Christians will evangelize as they greet ${ }^{22}$.

If by any chance some members of the family were undergoing hardship or trouble of any kind, messages of sympathy and consolation are passed to them through greetings ${ }^{23}$. So greetings become part of love to the brethren. People who often greet you will sympathize with you and show solidarity at the time of need. When people frankly greet you in African Christianity, they are simply saying 'you are good'. It is good that we have met. It is good that you have value. It is good that we are friends and so on. Greeting becomes an affirmation and appreciation of the other. So greetings do affirm people as people ${ }^{24}$.

The greeting of person serves as an invitation to share in the life of the other. When one spares time to greet you it means the person values you and the heart is opened to you. When faced with problems then you are assured of help by the one who greets you. And when one responds well to your greetings the person is assuring you of the same. If one is visiting a family, the family will show appreciation by saying you did well to come and greet us. Greetings are very important in African Christianity; they are the point of entry for people who are new to each other. It is in greeting that they open their hearts to each other for a conversation to begin. Greetings show a force which is immanent in all human beings, something as intangible and pervasive as 'the other'25. This is African spirituality which is enshrined in a belief; spirituality is the source of mission.

\section{Greetings as a Mission}

Therefore greetings are used in African Christianity for acceptance and reconciliation, this is a mission. If two people are not in talking mood, greeting each other would mean they have been reconciled or they are willing to be reconciled and cultivate friendship. In any reconciliation a hand shake will conclude the process. In this case humility is also expressed through greeting. Greetings as a mission brings a spirit of togetherness, love for others' relatives, neighbors and God. They show care for both loved and unloved as well as the

22. See Waweru, African Theology, 156.

23. See Waweru, The Bible and African Culture, 97, where he argues that, every faithful Christian must practice Christianity within a particular context.

24. Waweru, African Theology, 159.

25. See Waweru, The Bible and African Culture, 130. 
elderly. ${ }^{26}$ The relationship between family members as well as other community members is enhancing in greetings, which is an African mission, 'you are because I am and because you are I am'. This is an African 'mantra' which is embraced in the context of African mission systems.1

Greetings as a mission maintain community discipline. People are taken to be proud and arrogant if they don't greet others. For Ochieng-Odhiambo African Philosophy centers' on a person and his social context ${ }^{27}$, such could only be expressed through greetings as people evangelize each other. The individual is not taken as an impenetrable entity that lives in glorious isolation. The individual as Mbiti argues in his African Philosophy, is meaningless for one is because others $a^{28}{ }^{28}$. In African Christianity one will make sense only as part of the totality, for to be is to participate as. Mbiti puts it, 'there is already a dialogue taking place between the Christianity and the African religiosity ${ }^{29}$.

Greeting in this way of life require meeting. So when one meets the other in an African Christianity context, one must show the difference of meeting an animal or an object from a person. The person is not a thing, an object, a plant or even a tree. Failure to greet the other would imply you have reduced the other into an object. Hence greeting the other is an acknowledgment of the other as a live, valuable and present. When you hug or embrace the other, the message is clear you are not a thing, but somebody of value beyond even words. It would also imply you understand the other not as opposed to you but as to objects. Greetings in Africa mean that there must be something beyond creation and beyond our explanation. This can only be the God who is the source of their being ${ }^{30}$. This living power is beyond human comprehension and it transcends and permeates all being as expressed in the mission of greetings.

In African Christianity God is Spirit and is the source of greeting. Greeting comes from the Spirit of mission. This spirit connects you with the other. So greeting is one major way of expressing love to the other as you enquire more about the other. In greeting we do not just do it there is a formula inherited from our African cultural way of life. Greetings expresses the spirits as an integral part of the religious heritage for African mission, where people are deeply aware of the spirit world as affecting life experiences for better and for worse. Greeting come with meeting the other, a pronouncement of the formal verbal welcome, a brief enquiry about life past, present, and future and then parting wishing each other God's blessings. These four steps of greeting are vital to the whole process

26. See Waweru, The Bible and African Culture, 137.

27. See Ochieng'-Odhiambo, African Philosophy: An Introduction (Nairobi Consolata Institute of Philosophy Press, 1995), 43.

28. See J. S. Mbiti, African Religions and Philosophy,109.

29. See Mbiti, New Testament, 189, and Mbiti, "Future of Christianity," 32.

30. See Waweru, The Bible and African, 143. 
of greeting and evangelizing Africa ${ }^{31}$.

When greeting another person your conduct is very important. People must conduct themselves in a respectful way. It will also depend with whom you are greeting. For an age mate you do not need to be very formal. But when you are greeting people of other classes as well as ages carefulness is required in order to portray your utmost respect for them. Because greeting is sacred and puts you in touch with your inner self. And then moves you beyond self to connect you with mysterious other in the spirit world. The mysterious other has sacredness that also moves you when you meet compelling an urge to recognize the presence. Every Christian in Africa has a moral obligation to respond to this urge ${ }^{32}$. Greeting is not a tool of oppression but of freedom. The irony and paradox of greeting is that when we do not fulfill it, we feel burdened with a moral obligation which then burdens our hearts to do it in order to feel happy and peaceful.

\section{Greetings as a Fellowship}

It is one thing to envision a life of oneness in a community, and have the intention to pursue it through greetings; it is yet another thing to actually put this into practice. African wisdom teaches that the gap between individuals can be bridged through greetings. When two or more people greet each other with the explicit purpose of sharing life deeply, they can help one another discern the presence and leading of the spirit, and hold one another accountable for the life of obedience that flows from it ${ }^{33}$. What emerge from good greetings is the encouragement, admonition and exhortation of regular Christian fellowship which ends up becoming the heartbeat of mission oriented people. The bond created through greetings is of spiritual friendship which becomes the center of any community that seeks oneness in $\operatorname{God}^{34}$.

Greetings as fellowship, therefore, are rooted in the experiences that this kind of African Christian encounter develops. This mission oriented greetings becomes a real fellowship that makes Africans not only miss each other but seek that fellowship in order to help them envision their spiritual lives and remain faithful to their mission. Greetings are able in a unique way to create new areas of missions, by changing what may first appear as superficial contacts to face to face reality of fellowship, through thick and thin, for better and for worse. Greetings

31. Cf JNK. Mugambi, The African Heritage and Contemporary Christianity (Nairobi: Longman, 1989), 48.

32. See Mbiti, New Testament, 189, who argues that in carrying its mandate the church has to be loving, forgiving, reconciling, worshiping, and a living mission.

33. See P. R. Meadows, "Mission and Discipleship, in a Digital culture. Mission Studies," Journal of the International Association for Mission Studies, 29, no. 2 (2012): 179.

34. See Mbiti, African Religions and Philosophy, 108. 
throughout the centuries have demonstrated a Christian fellowship of penetrating the depths of true fellowship with others, in the common pursuit of knowing God $^{35}$.

Those who use greetings for mission must then be concerned with exploiting the full potential of fellowship for building a spirituality that embraces all people as brothers and sisters. Our participation in the mission of God is substantially expressed through greetings, in which God's love for our neighbors reaches out through us in a holistic way. From a biblical perspective Paul uses greetings to enhance his fellowship with the churches he had established during his missionary journeys. This way of life calls us to read the Bible contrapuntally ${ }^{36}$

\section{Paul uses Greetings to Enhance Mission}

Paul commonly greets the churches and individuals, greet all the saints in Christ Jesus. The brothers who are with me send greetings. All the saints send you greetings especially those who belong to Caesar's household (Phil 4:21-22). He greetings to enhance fellowship among brethren. He even sends individuals to specifically take greetings to some people. Tychicus will tell you all the news about me. He is a dear brother, a faithful minister and fellow servant in the Lord. I am sending him to you for the express purpose that you may know about our circumstances and that he may encourage your hearts (Col 4:7-8). So greetings do not only inform about our context they also encourage as well as educate other people. He further instructs Christians not to just greet but to do it in a way that will create impact. Greet all brothers with a holy kiss (1Athess 5:26). At times Paul will single out some people for the purpose of encouraging them. Greet Priscilla and Aquilla and the house hold of Onesiphorus. Erastus stayed in Corinth, and I left Trophimus sick in Melitus. Do your best to get here before winter Eubulus greets you, and so do pudens, linus, Claudia and all the brothers (2Tim 4:19-21). Africans using greetings for mission is letting the texts both the Bible and the African culture play each other ${ }^{37}$.

While in prison Paul sent greetings to the church and equally uses them to inform them of the help he has received from other people. Epaphras my fellow prisoner in Christ Jesus, sends you greetings. And so do Mark, Aristarchus, Demas and Luke, my fellow workers (Philemon 23-24). With the help of Silas, whom I regard as a faithful brother, I have written to you briefly encouraging you and testifying that this is the true grace of God. Stand fast in it. She who is in Babylon,

35. See Waweru, The Bible and African Culture, 144

36. See Waweru, "Reading the Bible Contrapuntally: A theory and a Methodology for a Contextual Bible Interpretation in Africa," in Swedish Missiological Themes, 94, no.3 (2006): 333-348.

37. See Waweru,Reading the Bible Contrapuntally, 339. 
chosen together with you, sends you greetings and so does my son Mark. Greet one another with a kiss of love (1Peter 5:12-13). The text here is calling upon Christians to re-examine their fellowship with other people; is there someone you need to forgive? Chose to do so rather than to punish them. Allow Christ to work through you to bring reconciliation between individuals and people groups. Greetings are powerful they allow a dead fellowship to be restored.

\section{Conclusion}

Therefore greeting as a tool for mission is able to bring people face to face with the other indefinable most mysterious of all creatures as a counter point ${ }^{38}$. Who is the mirror of my image and the reflection of my life whose actions and reactions goes deeper into my mind. Greeting moves the person beyond their ego into the heart of the other for blessings and warmth of Christianity. Greetings puts person into a relationship not only of the other but also with God who is the source of all life and goodness, hence the conversion. So greeting is a religious ritual, a religious performance and a religious experience that climaxes in worship to the almighty God. Greeting puts humanity in touch with the very being of the other spiritual world which makes the people end up in worshipping the creator. God is good that we have meet greeted and praised. When two people embrace each other in greeting something deep happens, their hearts are opened to each other and are made to perceive the power of fellowship. Greeting brings two hearts together that break into the worship of God. Therefore, when we examine greetings as a tool for mission leading to conversion, it is important to think in terms of indigenous systems of knowledge that could enhance mission in all areas of life.

This paper has attempted to demonstrate that greetings can be used as a tool for mission in Africa as well as other parts of the world. It is reasonable to expect that upon investigation, scholars may find many such instances in which the initial object of greetings becomes the means by which mission is enhanced as a process of transformation initiated by the missionary encounter. Furthermore, thinking of greetings in terms of mission can deepen our understanding of both the process of evangelization as well as the process of behavior change. Thus important connections between greetings and mission become a theology of transformation which is not merely unidirectional favoring the traditional African greetings but is rather dialectic between indigenous practice and the Christian message.

38. See Waweru, Reading the Bible Contrapuntally, 341. 


\section{Bibliography}

Boer, R. "Remembering Babylon: Postcolonial and Australian Biblica studies." In The Postcolonial Bible, edited by Sugirtharajah. Sheffield: Sheffield Academic Press, 1998.

Brown, David A. A Guide to Religions. London. SPCK, 1975.

Draper, A. J. 2002.Reading the Bible as Conversation: A Theory and Methodology for Contextual Interpretation of the Bible in Africa, in Grace \& Truth, Vol 19, 2 (2002), p 13-25.

Mbiti, J. S. African Religions and Philosophy. London: Heinemann, 1969.

. "The Future of Christianity in Africa (2000)."Communio Viatorum 13, nos. 1-2 (1970): 32-33.

. New Testament Eschatology in an African Background. London: Oxford Univ. Press, 1971.

. "Some African Concepts of Christology." In Christ and the Younger Churches, Theological Collections no. 15, edited by G. F. Vicedom, London: SPCK, 1972.

Geertz, C. "Ethos, Worldview and the Analysis of Sacred Smbols." In Every Man his Way: Reading in Cultural Anthropology, edited by A. Dundes. Engle Wood Cliffs. New Jersey: Prentice Hall, 1968.

Meadows P. R. "Mission and Discipleship, in a Digital culture. Mission Studies." Journal of the International Association for Mission Studies. 29 no. 2 (2012): 161182.

Mugambi, JNK. The African Heritage and Contemporary Christianity. Nairobi: Longman, 1989.

Ochieng'-Odhiambo, F. African Philosophy: An Introduction. Nairobi Consolata Institute of Philosophy Press, 1997.

Oduyoye, Mercy. "Claiming our Heritage: Africa in World Christianity (AsanteOpoku-Reindorf Lecture 2008)." In Journal of African Christian Thought 12, no. 2 (December 2009): 3-9.

Oden, Thomas C. How Africa Shaped the Christian Mind, Rediscovering the African seedbed of Western Christianity. Downers Grove, IL: IVP, 2007.

Shorter, A (ed). Church and Marriage in East Africa. Eldoret: A.M.EC.E.A, 1975.

Stott, John. The Incomparable Christ. Downers Grove, IL: IVP, 2000.

Tunner, V.H.1967. African Independent Church: History and Life and Faith of the Church of the Lord Alandura, Vol.II. London> Oxford University Press.

Walls, A. The Cross-Cultural Process in Christian History. Maryknoll, Orbis, 2002.

Waweru H. 2005. A Critical Analysis of the Vision of the New Jerusalem in the Light of the Kikuyu dreams and Visions: Unpublished PhD Thesis. University of KwaZulu- Natal. Pietermaritzburg.

"Reading the Bible Contrapuntally: A theory and a Methodology for a Contextual Bible Interpretation in Africa." In Swedish Missiological Themes, 94, no. 3(2006): 333-348. 
The Bible and African Culture: Mapping Transactional Inroads. EldoretKenya: Zapf Chancery, 2011.

African Theology in a Postcolonial Perspective. Limuru, Kenya. Franciscan Kolbe Press, 2020. 